\title{
Patch clamp brings honour
}

\section{London}

THIS year's Nobel prize for physiology or medicine has gone to Erwin Neher and Bert Sakmann, two German electrophysiologists who in the mid-1970s transformed cell physiology with their invention of 'patch clamp' recording from cell membranes.

Neher and Sakmann made it possible for the first time to record the electrical activity of very small areas of membrane, so that the effects of opening and closing single ion channels could be observed. In their pioneering paper, published in $\mathrm{Na}$ ture $(\mathbf{2 6 0}, 799 ; 1976)$, the pair described how a minute area of cell membrane could be isolated electrically by pressing the tip of a glass pipette, less than $5 \mu \mathrm{m}$ in diameter, against the cell surface. With this pipette fitted with a recording electrode, Neher and Sakmann confirmed that when the membrane potential of a cell alters rapidly - for example, in response to an action potential - ions cross the cell membranes through channels releasing one ion at a time.

The patch-clamp technique revolutionized cell physiology, improving the sensitivity of previous recording techniques by a million-fold. For the first time, physiologists were able to study the minute changes in current (around 1 picoampere) caused by the movement of ions through a single ion channel, essentially studying in real time the activity of the single protein molecule that regulates each channel.

Combining the sensitivity of patchclamp recording with the techniques of molecular biology, it has been possible to examine how mutations causing single amino acid changes in membrane proteins affect the behaviour of individual ion channels.

The patch-clamp method has also been used to study the electrical activity of entire cells. By penetrating a cell with a pipette, it is possible not only to make electrical recordings but also to manipulate the internal environment of the cell by adding ions or second messenger molecules. Before the patch-clamp method, whole cell recordings were possible only from extremely large - and by no means typical - cells, such as giant axons in snails and oocytes of sea urchins.

Several recent Nobel prizes have engendered some controversy, notably the claim by the French researcher Dominique Stehelin that he should have shared the 1989 medicine prize awarded to Michael Bishop and Harold Varmus (Nature 341, 556; 1989). But Neher and Sakmann's award seems to be refreshingly free from such disputes. "There's absolutely no doubt at all that the credit for this method lies with Neher and Sakmann," says David Colquhoun, from University College London.

The only complaint expressed by some physiologists is that the Germans had to wait so long for their prize. David Clapham, a former post-doctoral researcher in Neher's laboratory now at the Mayo Clinic in Minnesota, recalls from his post-graduate days the immediate impact that the 1976 Nature paper had on the field. "We have expected this for almost ten years," adds Clapham's Mayo colleague Julio Fernandez, also a veteran of Neher's laboratory.

Peter Aldhous

\section{DOE won't wait on WIPP}

\section{Washington}

ThE US Department of Energy (DOE) announced last week that it will wait no longer for congressional action on its Waste Isolation Pilot Plant (WIPP) in New Mexico, but instead will begin testing at the nuclear waste disposal test project as soon as possible. That may not be too soon, however, as the New Mexico attorney general has said he will seek to block the move in court.

WIPP is the energy department's main research and development facility for the disposal of nuclear wastes from weapons manufacture. It is designed to store approximately 6.5 million cubic feet of waste contaminated by plutonium and other transuranic elements in a salt repository some 2,150 feet underground.

On 3 October, Admiral James Watkins, Secretary of Energy, announced that WIPP is ready to begin testing, and all that remains to been done is to withdraw the land containing the site from the public domain and put it under the control of DOE. The department has been negotiating with Congress on a bill that would provide for the land withdrawal and in return provide some $\$ 600$ million to New Mexico in federal benefits.

Those negotiations have been stalled, however, on the question of how much waste WIPP will be allowed to accept in its initial 'performance assessment testing'. On the recommendation of the Environmental Protection Agency (EPA), the energy department insists that it should be allowed to bring as much as $\mathbf{8 , 5 0 0}$ barrels of waste - 1 per cent of capacity - into the facility. New Mexico senator Jeff Bingaman is demanding that the limit should be 4,250 barrels and that the DOE should be required to obtain approval from Congress to exceed that amount.

In the face of this impasse, Watkins decided to bypass Congress altogether. The WIPP site has been under the control of the Department of the Interior since 1983 , and under existing legislation it can be transferred to the energy department without the approval of Congress if the DOE certifies it has met all environmental requirements for WIPP. Watkins sent that certification on 3 October. The energy department would prefer Congress to carry out the land withdrawal, Watkins said, but "not at the cost of running WIPP in an unsound manner".

Although the governor of New Mexico is in favour of proceeding with WIPP, the attorney general - the state's senior law enforcement officer - has said he will bring suit in court to oppose administrative land withdrawal. If he does, it is likely to be an expensive suit: DOE has promised to pay $\$ 63$ million to New Mexico once WIPP is under way, but it has said it will withhold the money if the state takes any legal action.
Robert Pool and function of macromolecules and membrane transport. Details of the programme 